\title{
Impact of Cash Transfer on Food Security: A Review
}

Fatemeh Mohammadi-Nasrabadi*

1- Dept.of Food and Nutrition Policy and Planning Research, National Nutrition and Food Technology Research Institute, Faculty of Nutrition Sciences and Food Technology, Shahid Beheshti University of Medical Sciences, Tehran, Iran.

\section{A B S T R A C T}

Cash transfer (CTs) is an increasingly popular social protection mechanism used by many developing countries to improve the food security and nutritional status of lower socio-economic groups.

This paper is a review of the literature regarding the impact of CT programs on the food security of recipient households in the developing countries, including Iran. We looked for all original studies, performed in the developing countries and published in any language, containing at least one outcome related to food and nutritional security of the beneficiary population using Pub Med, Iran Medex, SID (Scientific Information Database), ISI (Information Sciences Institute) database, INP (Iran's Nutrition Publication) Abstracts, IRANDOC and Magiran. Searches used the following terms or keywords: "household food security", "household food insecurity" and "cash transfer" on any publication published within 1990-2015.

A total of 12 studies evaluating the influence of CT programs on the recipients' food and nutrition security were identified. CT programs have the potential to deliver a range of benefits not only through reducing extreme poverty but also by providing effective support for broader human development objectives, including better nutrition, as well as health and education outputs and outcomes. The extent to which programs can have these different impacts will depend critically on the availability of complementary services, the local context, and the specifics of program design, including the transfer value. However, findings in Iran suggest that the replacement of staple food subsidies by $\mathrm{CT}$ has led to a significant increase in household food insecurity (especially marginal or mild food insecurity).

Keywords: Household food security, Cash transfer, Developing countries

\section{Introduction}

"Social protection" encompasses a broad set of public and private systems for protecting people against risks to their livelihoods and keeping them from falling into (or deeper into) poverty. Engender long-term, sustainable development processes in the hope of providing opportunities for people to move out of poverty and achieving higher standards of living can be achieved through interventions that invest in assets, including the health, nutrition and education of children and adults, and improved social status and rights. In addition, social protection can be seen as contributing to growth through investments in human capital, development of infrastructure, strengthening of markets, and maintenance of political stability (1).

Cash transfers (CTs) are increasingly popular social protection mechanisms used by many developing countries to improve the food security and nutritional status of lower socio-economic groups. These programs aim not only to alleviate current poverty through income transfers but also to reduce future poverty by encouraging investment(s) in human capital, education, health and nutrition. The overall objective of the program can, therefore, be seen as 
preventing the intergenerational transmission of poverty. In practice, two major types of cash transfer programs have been implemented: First, unconditional CT (UCT) that has been used mostly in the sub-Saharan Africa and also recently in Iran. In these programs, CTs are given to poor and vulnerable people with no restrictions on how the cash is spent, and no requirements beyond meeting the eligibility criteria (for example, being poor, orphan, or over 60 years of age). The primary objective is to protect current consumption or food security. By contrast, the second type, conditional cash transfers (CCTs) are delivered only on condition that recipients meet certain requirements; for instance, their children should be enrolled in school, and they must be immunized. CCTs have dominantly been used throughout the Latin American countries. Research to date has been more successful in showing short-term impacts on human capital; however, there is not much data available on achievement of the broader goal. A review conducted by the World Health Organization (WHO) on several CCT programs provided strong evidence of a positive impact on the use of health services, nutritional status and health outcomes, which are assessed by anthropometric measurements and self-reported episodes of illness, respectively. It is hard to attribute these positive effects to the cash incentives specifically because other components may also contribute (2). However, evidence from UCT of several countries has confirmed that recipients invest some of their cash transfers in education and health anyway (3). Interest in and the scope of CCT programs have grown enormously in the last 10 years (4).

\section{Materials and Methods}

A review of the literature was performed centered on the guiding question: "Are CT programs capable of affecting the food security of the recipient households?" Concerning the inclusion criteria, we looked for original studies, performed in the developing countries and published in any language, containing at least one outcome related to food and nutritional security of the beneficiary population using Pub Med, Iran Medex, SID (Scientific Information Database), ISI (Information Sciences Institute) database, INP (Iran's Nutrition Publication) Abstracts, IRANDOC and Magiran. Both clinical (random or otherwise) and observational (crosssectional, longitudinal, with and without control group) studies published within 1990-2015 were included.

Searches used the following terms or keywords: "household food security", "household food insecurity" and "cash transfer". Additional studies (grey literature) were identified by searching the reference lists of identified articles. The abstracts of all identified studies were read to exclude those that were irrelevant. The full texts of the remaining articles were read to determine whether they met the inclusion criteria. Those publications that did not contain the required data for the review were omitted. The following information was extracted from the remaining 12 relevant studies: author(s), year of publication, place, coverage and participants, measuring outcome(s), main conclusion and methodological limitations.

\section{Results}

Based on the findings of the reviewed papers, one of the strongest and most consistent findings regarding the impact of $\mathrm{CT}$ programs is their contribution to reducing hunger and food insecurity. Regardless of the form of transfer, households receiving transfers average significantly higher spending on and consumption of food (5). Table 1 presents a summary of the studies on cash transfer impacts on various aspects of food security.

The impact of CTs on hunger has been most pronounced in low-income countries (LICs) where poverty is generally more severe. In these settings, households receiving additional income are particularly likely to prioritize spending on improving the quantity and/or quality of food consumed. For example, in Ethiopia, the Productive Safety Nets Program (PSNB) has improved food security in 7.8 million people who were previously depended on emergency relief. The program operates in 300 rural districts facing chronic food shortage and provides food or cash for work as well as UCTs or food aid to those unable to participate in public works. Threequarters of the participants consumed higher quantity and quality of food compared to the previous year, and 60 percent had avoided selling off their productive assets to buy food (6). Households receiving cash had better dietary diversity than those receiving food, suggesting that CTs may be more effective $(7,8)$. 
Table 1. Description of the studies evaluating the influence of cash transfer programs on the recipients' food and nutrition security (1990-2015)

\begin{tabular}{|c|c|c|c|c|c|c|}
\hline Author(s) / year & Study design & Setting/ Program & Subjects/Sampling & $\begin{array}{l}\text { Measurement Tool(s) of } \\
\text { Outcome (FI) }\end{array}$ & Main conclusions & Methodological limitations \\
\hline $\begin{array}{l}\text { Baye et al. (2014)(7) and } \\
\text { Gilligan et al. (2008)(8) }\end{array}$ & $\begin{array}{l}\text { Cross-sectional survey of } 195 \\
\text { PSNP beneficiary households }\end{array}$ & Ethiopial PSNP & $\begin{array}{l}8.3 \text { million chronically food } \\
\text { insecure households in } 319 \\
\text { district with predictable cash } \\
\text { and/or food transfers during lean } \\
\text { months }\end{array}$ & $\begin{array}{l}\text { Shortfall in caloric } \\
\text { availability, } \\
\text { Daily per capita caloric } \\
\text { acquisition }\end{array}$ & $\begin{array}{l}\text { Prevalence and severity of the } \\
\text { chronic food insecurity experienced } \\
\text { by poor households reduced }\end{array}$ & $\begin{array}{l}\text { Data were collected more than one } \\
\text { year after the program began }\end{array}$ \\
\hline $\begin{array}{l}\text { Seidenfeld et al. }(2014)(9 \text {, } \\
\text { 10) }\end{array}$ & Randomised controlled trial & $\begin{array}{l}\text { Zambia/ } \\
\text { Child Grant Programme }\end{array}$ & $\begin{array}{l}2,515 \text { households }(1260 \\
\text { treatment and } 1259 \text { control }) / \\
\text { randomly selected }\end{array}$ & $\begin{array}{l}\text { FANTA food } \\
\text { insecurity score }\end{array}$ & $\begin{array}{l}\text { cash transfers improve household } \\
\text { consumption, food consumption, } \\
\text { diet diversity and food security }\end{array}$ & $\begin{array}{l}\text { The increase in agricultural production } \\
\text { did not lead to an increase in } \\
\text { consumption of goods produced on } \\
\text { farm }\end{array}$ \\
\hline $\begin{array}{l}\text { Harvey }(2012) \text {, } \\
\text { MacAuslan and Schofield } \\
(2011)(12,13)\end{array}$ & $\begin{array}{l}\text { Simple random sample of } 170 \\
\text { enrolled voucher recipients }\end{array}$ & $\begin{array}{l}\text { Nairobi, Kenya/ Safety } \\
\text { Net Program }\end{array}$ & $\begin{array}{l}5,000 \text { households }(2,000 \text { in } \\
\text { Korogocho and } 3,000 \text { in } \\
\text { Mukuru) }\end{array}$ & $\begin{array}{l}\text { HDDSIDDS and } \\
\text { HFIAS }\end{array}$ & $\begin{array}{l}\text { Statistically significant decrease of } \\
23.7 \text { percentage in severe food } \\
\text { insecurity }\end{array}$ & $\begin{array}{l}\text { The low coverage rate compared to } \\
\text { the levels of } \\
\text { extreme poverty }\end{array}$ \\
\hline $\begin{array}{l}\text { Ministry of Gender, } \\
\text { Children and Social } \\
\text { Protection, } 2013(34)\end{array}$ & & $\begin{array}{l}\text { Ghana/ Livelihood } \\
\text { Empowerment Against } \\
\text { Poverty (LEAP) }\end{array}$ & $\begin{array}{l}71,000 \text { households in all } 10 \\
\text { regions }\end{array}$ & 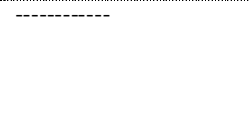 & $\begin{array}{l}\text { Food insecurity has significantly } \\
\text { reduced (by } 25 \text { percentage points) } \\
\text { especially for those headed by } \\
\text { women }\end{array}$ & $\begin{array}{l}10 \text { (Rural) } \\
10 \text { (Urban) }\end{array}$ \\
\hline Dewber et al. (2015), (35) & 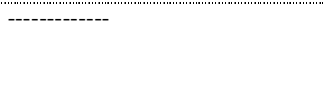 & $\begin{array}{l}\text { Lesotho/ Child Grant } \\
\text { Programme (CGP) }\end{array}$ & $\begin{array}{l}299 \text { households and } 1571 \\
\text { individuals }\end{array}$ & 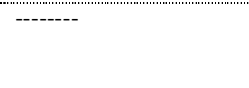 & $\begin{array}{l}\text { Increased food purchases, especially } \\
\text { for the unconstrained }\end{array}$ & $\begin{array}{l}\text { Data constraints limit the possibility } \\
\text { of understanding the time use } \\
\text { implications }\end{array}$ \\
\hline Baired et al. (2011)(36) & $\begin{array}{l}\text { Longitudinal, randomized } \\
\text { community control study of the } \\
\text { pilot SCTS in Mchinji }\end{array}$ & $\begin{array}{l}\text { Malawi Social Cash' } \\
\text { Transfer (SCT) }\end{array}$ & $\begin{array}{l}\text { about } 1000 \\
\text { households in } 29 \text { villages }\end{array}$ & $\begin{array}{l}\text { A structured } \\
\text { quantitative } \\
\text { questionnaire }\end{array}$ & $\begin{array}{l}\text { A tremendous gain in food security } \\
\text { within intervention households. }\end{array}$ & $\begin{array}{l}\text { Each of the tested outcomes yields } \\
\text { large effect sizes that are highly } \\
\text { statistically Significant }\end{array}$ \\
\hline Roman et al., $2010(37)$ & Five sets of household surveys & $\begin{array}{l}\text { Zimbabwe/ Harmonized } \\
\text { Social Cash Transfer } \\
\text { (HSCT) }\end{array}$ & $\begin{array}{l}\text { Average of } 29,300 \text { beneficiaries } \\
\text { in almost } 6,000 \text { households }\end{array}$ & (n) & $\begin{array}{l}\text { ZECT had an important effect on } \\
\text { households' monthly livelihoods. }\end{array}$ & $\begin{array}{l}\text { Inability to find the same households } \\
\text { every month and time constraints } \\
\text { affecting monitor flexibility to travel } \\
\text { to far apart locations. }\end{array}$ \\
\hline $\begin{array}{l}\text { Segal-Correa et al., } 2004 \\
\text { (38) }\end{array}$ & $\begin{array}{l}\text { Cross-sectional } \\
\text { Study }\end{array}$ & $\begin{array}{l}\text { Brazil } \\
\text { (secondary } \\
\text { data from PNAD) }\end{array}$ & $\begin{array}{l}56,037 \text { B razilian households } \\
\text { with per capita income below } \\
\mathrm{R} \$ 260.00\end{array}$ & $\begin{array}{l}\text { Food security or mild } \\
\text { and } \\
\text { Moderate or severe } \\
\text { FI (EBIA) }\end{array}$ & $\begin{array}{l}\text { Increasing the value of the cash } \\
\text { transfer by } R \$ 10.00 \text { increases } \\
\text { the family's chance of food security } \\
\text { by } 8 \% \text { after adjusting for socio- } \\
\text { demographic variables. }\end{array}$ & $\begin{array}{l}\text { Cross-sectional study means no } \\
\text { conclusions could be drawn on the } \\
\text { effects of the program. }\end{array}$ \\
\hline Vianna et al., 2005(39) & $\begin{array}{l}\text { Population } \\
\text { based cross-sectional } \\
\text { study }\end{array}$ & $\begin{array}{l}\text { 14 Municipalities in } \\
\text { Paraiba in 2005, School } \\
\text { grant, Gas tickets,Food } \\
\text { grant, Family grant }\end{array}$ & 4,533 families & $\begin{array}{l}\text { Families food security, } \\
\text { mild and Moderate or } \\
\text { severe FI (EBIA) }\end{array}$ & $\begin{array}{l}\text { Comparing families with per capita } \\
\text { income < } \$ 225.00 \text {, a lower } \\
\text { prevalence of severe FI in families } \\
\text { registered in the CCTP (reduction of } \\
4.8 \% \text { ), after adjusting for income. }\end{array}$ & $\begin{array}{l}\text { It was not possible to classify the } \\
\text { families on more than one minimum } \\
\text { wage/month. }\end{array}$ \\
\hline Dias et al., $2009(40)$ & $\begin{array}{l}\text { Population based cross-sectional } \\
\text { study/ PBF, municipal program } \\
\text { Cesta Cheia, Família Feliz }\end{array}$ & $\begin{array}{l}1 \text { primary health care } \\
\text { unit in a municipality in } \\
\text { the Southeast }\end{array}$ & $\begin{array}{l}172 \text { families receiving } \\
\text { Programas } \\
\text { Bolsa Família and Cesta Cheia, } \\
\text { Família Feliz }\end{array}$ & $\begin{array}{l}\text { Food security, mild and } \\
\text { moderate } \\
\text { or severe FI (EBIA) }\end{array}$ & $\begin{array}{l}28.0 \% \text { were found to have food } \\
\text { security and } 12.0 \% \text { to have severe } \\
\text { food insecurity. Increased income } \\
\text { lead to significant drops in food } \\
\text { insecurity }(\mathrm{p}<0.01) \text {. }\end{array}$ & $\begin{array}{l}\text { Cross-sectional study means causal } \\
\text { relationships between the dependent } \\
\text { variable (food insecurity) and the } \\
\text { independent variables cannot be } \\
\text { proved. }\end{array}$ \\
\hline $\begin{array}{l}\text { Mascie-Taylor et al., } \\
2009(20)\end{array}$ & The panel study & $\begin{array}{l}\text { Bangladesh (cash-for- } \\
\text { work programme) }\end{array}$ & $\begin{array}{l}\text { Random sample of } 895 \\
\text { households and } 921 \text { control }\end{array}$ & $\begin{array}{l}\text { 7-day household food } \\
\text { expenditure and } \\
\text { consumption }\end{array}$ & $\begin{array}{l}\text { Intervention households spent more } \\
\text { on food and consumed more } \\
\text { protein-rich food }\end{array}$ & $\begin{array}{l}\text { Information on the actual quantity of } \\
\text { food consumed by women and their } \\
\text { children was not available, }\end{array}$ \\
\hline $\begin{array}{l}\text { Mohammadi et al. } \\
(2015)(31)\end{array}$ & Longitudinal study & All recruited Iranians & Iranian targeted subsidy plan & HFIAS & $\begin{array}{l}\text { Mild food insecurity has increased } \\
\text { from } 19.3 \% \text { to } 28.4 \%\end{array}$ & $\begin{array}{l}\text { Data were available only in Tehran } \\
\text { city, not in rural areas. }\end{array}$ \\
\hline
\end{tabular}

HFIAS: Household Food Insecurity Access Scale CCTP: Conditional Cash Transfer Programs FI: Food insecurity
EBIA: Brazilian Scale of Food Insecurity

PNAD: National Household Survey; PBF: Family grant program FANTA: Food and Nutrition Technical Assistance Project 
The Child Grant Program (CGP) is one of the Government of Zambia's largest social protection programs. The program provides a monthly cash payment of 60 kwacha (US\$12) to very poor households with children under five years old. A randomized controlled trial of 2,515 households was implemented to investigate the impact of the program. CT had resulted in the overall improvement in the consumption, food consumption, diet diversity, and food security of the households $(9,10)$.

In Nairobi's informal settlements, Oxfam and Concern Worldwide (OCW) developed a joint CT programs to address improving food and livelihood security of the most food-insecure households in Kenya by increasing their immediate access to food and developing longer-term initiatives to improve their access to food and income security $(11,12)$. During the baseline assessment, almost all the interviewed households (97.4\%, N=156) were classified as severely food insecure according to the Household Food Insecurity and Access Scale (HFIAS). By the end of the program, a statistically significant decrease of 23.7 percentage was observed. The mean HFIAS score at end-line was $13.2 \pm 4.8$ compared to $18.8 \pm 3$ (the highest possible score of 24 represents total food insecurity)(13).

Also an evaluation of Malawi's CT program showed that around 75 percent of the transfer had been spent on groceries (14).

A positive association between Brazilian CCT programs and improvement in the recipients' diet and nutrition have also been reported (15). CCTP have made a positive contribution, especially in tackling social inequalities, decreasing levels of malnutrition, and reducing infant mortality in Brazilian municipalities (16).

Whilst there are variations across programs; on average, roughly half the value of transfers is expected to be spent on food, one third on household expenses, and the rest on health, education and savings or investment. A synthesis of findings from surveys in sub-Saharan Africa found that in six out of the seven programs reviewed, the primary use of CTs was to purchase food (17). This increase in expenditure and food availability can translate into improvements in nutritional indicators, particularly for vulnerable groups. In South Africa, econometric analysis of anthropometric survey data estimates that a boy receiving the Child Support Grant in early childhood (specifically for two thirds or more of the first three years of life) obtains an increase in heightfor-age at age 3 which can be expected to result in an average of $3.5 \mathrm{~cm}$ gain in height as an adult (18).

In Nicaragua, after two years, malnutrition in children in the households receiving CTs from the RPS (conditional cash transfer (CCT) program) reduced 1.7 times greater than the national trend (19). Also in Lesotho, 48 percent of the old age pensioners reported that they never went hungry after the introduction of the old age pension, compared to the 19 percent before (14).

In Bangladesh's Chars Livelihood Program (CLP), nutritional surveys in 2009 found that children of earlier recruits into the cash and asset transfer program were, on average, less stunted and underweight than the later recruits (5). A cash for work program with no complementary nutrition program showed a significant impact on growth after an average of just 10 weeks among women (mid upper arm circumference $2.3 \mathrm{~mm}$ larger and body weight $0.88 \mathrm{~kg}$ higher than in the control group) and children $(0.12 \mathrm{~mm}$ and $0.17 \mathrm{~kg}$ weight for age). Intervention households spent more on food and consumed more protein-rich food at the end of the study (20).

Most studies quantifying the impact of CTs on nutrition, hunger or food security identify a positive impact though a wide range of methodologies are used, making it difficult to generalize about the size of impact. A detailed review of the links between transfers and improved child nutrition by Save the Children (SCF) has identified how CTs can address the causes of malnutrition (in particular the economic determinants of chronic malnutrition) at immediate, intermediate and structural levels (21). The 2009 SCF report found that the size of gains in child nutrition arising from transfer programs depend on three key design features: the duration over which the transfer is received, the age of recipient (given the importance of the window between 0-24 months of age), and the size of transfer. Conditionality may also be a factor as whether complementary services are offered alongside (e.g. nutritional supplements). For example, a UCT program in Mozambique showed little or no 
impact on nutrition, probably because of the low value of the transfer ( $£ 1.2$ to $£ 2.4$ per month, less than a third of household expenditure). A CCT in Honduras showed little impact, which is similarly considered to be due to low transfer value and lack of complementary services.

In some cases, CTs also generate a positive impact on the supply of food. CTs can affect local markets, by generating increased demand that can, in turn, trigger a supply response by local producers (22). In remote rural areas of South Africa, CTs have stabilized the demand for food, reduced market risk for producers and traders, and supported local agricultural production (23). Households receiving South Africa's Child Support Grant, for example, have demonstrated greater resiliency in maintaining agricultural production (22). Recipients of Bolivia's BONOSOL program in poor rural areas experienced an average increase in food consumption of almost 165 percent of the value of the transfer. This was achieved through the investment of part of the transfers in much needed agricultural inputs. Conversely, where markets are not able to respond by increasing supply in this way, CTs can have a negative impact by pushing up local prices. In Ethiopia, evidence from the Meket Livelihoods Program (MLP) demonstrates that shifting from food to cash-based transfer programs had negative implications for the availability and price of food in local markets, especially in remote, food-deficit areas, undermining prospects for both graduation and growth (24).

The Iranian targeted subsidy plan, also known as "The Subsidy Reform Plan" was passed by the Iranian Parliament in 2010. The goal of this plan was to replace subsidies on food and energy (80\% of total) with targeted social assistance in accordance with the Five Year Economic Development Plan (2010-2015) and a move towards free market prices in a 5-year period (25-27). Previous studies on the effectiveness of food subsidy before cash transfer in Iran have indicated the positive effect of staple food subsidy on the energy and protein intake of low socio-economic groups (28, 29).
In the study conducted by National Nutrition and Food Technology Research Institute (NNFTRI) and Academy of Medical Sciences (AMS), aimed at evaluation of subsidy targeting program through CT on the food security and expenditure of urban population in Tehran by using a mixed method, the population included households from six districts with different socio-economic status in the city of Tehran. Data gathered in both periods, 2009 (before) and 2012 (after) implementation of the policy, included: a) Demographics and household expenditure; b) Food security by previously validated Household Food Insecurity Access Scale (HFIAS)(30); and c) Dietary intake by three consecutive 24-hour recalls. In addition, data on household coping strategies were collected through 7 focus group discussions with women from different districts. The discussions were audio taped and transcribed.

The frequency of food secure households has declined from $56.4 \%$ to $43.5 \%$, mild food insecurity has increased from $19.3 \%$ to $28.4 \%$, moderate food insecurity has risen from $13.3 \%$ to $15.5 \%$, and severe food insecurity has grown from $11 \%$ to $12.5 \%$ in the second measurement. Consumption survey showed significant decrease in consumption of fruits, meat and dairy groups after changing commodity subsidy program to CT in the households residing in Tehran $\left(p<0.0^{\circ}\right)(31)$. Most of the women studied reported strategies like loaning or borrowing from family and friends and spend the savings to compare the increased food and other prices such as transporting and fuel. In the face of initial manifest goals of the subsidy-targeting program through CT to reduce social inequalities and poverty at multiple levels, this program has, in practice, increased the relative deprivation and social gaps in the residents of Iranian metropolises like Tehran (32).

Although CT appears to enjoy many advantages over in-kind transfers, the recent evidence shows that CTs might be inappropriate in weak economies, and most CT programs have been unable to raise payment rates in line with price inflation (Table 2 and Figure 1)(33). 
Table 2. Cash versus food transfers: advantages and disadvantages (33)

\begin{tabular}{|c|c|}
\hline Food & Cash \\
\hline \multicolumn{2}{|c|}{ Advantages } \\
\hline $\begin{array}{l}\text { - Donor food surpluses are } \\
\text { available } \\
\text { - Immediately increases food } \\
\text { availability } \\
\text { - Directly addresses nutritional deficits } \\
\text { - Can be self-targeting } \\
\text { - Usage favours women, children, } \\
\text { - older persons } \\
\text { - Lower security risk }\end{array}$ & $\begin{array}{l}\text { - More cost-efficient than food } \\
\text { - Beneficiaries choose what to } \\
\text { spend on } \\
\text { - Encourages production } \\
\text { - Stimulates the market }\end{array}$ \\
\hline \multicolumn{2}{|c|}{$\begin{array}{l}\text { Disadvantages } \\
\end{array}$} \\
\hline $\begin{array}{l}\text { - High transport and storage costs } \\
\text { - Losses from spoilage and theft } \\
\text { - Less easily exchanged than cash } \\
\text { - Might discourage local production } \\
\text { - Competes with local markets and } \\
\text { trade }\end{array}$ & $\begin{array}{l}\text { - Limited donor resaurces are } \\
\text { available } \\
\text { - Losses from inflation } \\
\text { - Can be used for non-food } \\
\text { consumption } \\
\text { - More difficult to target } \\
\text { - Usage favours men } \\
\text { - Heightened security risk }\end{array}$ \\
\hline
\end{tabular}

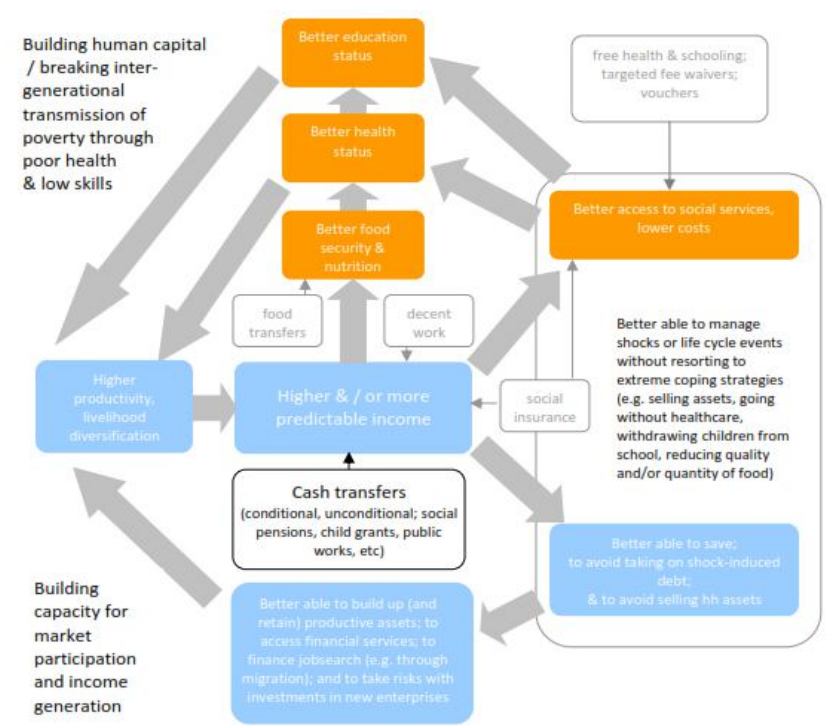

Figure 1. Causal pathways by which cash transfers can improve household welfare (5).

\section{Conclusion}

In sum, CT programs have the potential to result in a range of benefits, from reducing extreme poverty to effective support for broader human development objectives, including better nutrition, as well as health and education outputs and outcomes. The extent to which programs deliver these different impacts will depend critically on the availability of complementary services, the local context, and the specifics of program design, including the transfer value. There is some, more limited, evidence that well-designed CT programs can contribute to women's empowerment, local economic activity, strengthening the 'contract' between the citizens and the state, and supporting climate change adaptation. This is principally a result of needing to focus more in these areas in program monitoring and evaluation, rather than a failure to find results in these areas in existing evaluations.

\section{Acknowledgement}

This review has been conducted in the National Nutrition and Food Technology Research Institute (NNFTRI). The author is grateful to the director and personnel of NNFTRI. Also especial thanks to Dr. Nasrin Omidvar for her valuable comments.

\section{Financial disclosure}

The author declared no financial interest.

\section{Funding/Support}

This research was done with the financial support by National Nutrition and Food Technology Research Institute.

\section{References}

1. Adato M. Integrating survey and ethnographic methods to evaluate conditional cash transfer programs. Washington, DC: International Food Policy Research Institute, 2008.

2. Lagarde M, Haines A, Palmer N. The impact of conditional cash transfers on health outcomes and use of health services in low and middle income countries (Review). UK: The Cochrane Collaboration. Published by JohnWiley \& Sons, Ltd., 2009.

3. Pega F, Liu S, Walter S, Lhachimi S. Unconditional cash transfers for assistance in humanitarian disasters: effect on use of health services and health outcomes in low- and middle-income countries (Review). The Cochrane Collaboration: John Wiley \& Sons, 2015 Contract No.: 9.

4. Fiszbein A, Schady N, Ferreira FHG, Grosh M, Keleher N, Olinto P, etal. Conditional Cash Transfers: Reducing present and future poverty. Washington DC: The World Bank, 2009.

5. DFID, UKaid. DFID Cash Transfers Literature Review. London, UK: Department for International Development, UKaid, 2011.

6. Devereux S, Coll-Black S . Review of evidence and evidence gaps on the effectiveness and impacts of DFIDsupported pilot social transfer schemes. UK: DFID Evaluation Working Paper (Unpublished), 2007.

7. Baye K, Retta N, Abuye C. Comparison of the effects of conditional food andcash transfers of the Ethiopian Productive Safety Net Program on household food security and dietary diversity in the face of rising food prices: Ways forward for a more nutrition-sensitive program. Food Nutr Bull. 2014;35(3):289-95.

8. Gilligan DO, Hoddinott J, Taffesse AS. An analysis of Ethiopia's Productive Safety Net Program and its 
linkages. Washington, D.C.: International Food Policy Research Institute, 2008.

9. Seidenfeld D, Handa S, Tembo G. Social Cash Transfer Scheme: 24-Month Impact Report forthe Child Grant Programme. Washington, DC: American Institute of Research, 2013.

10. Seidenfeld D, Handa S, Tembo G, Michelo S, Scott CH, Prencipe L. The Impact of an Unconditional Cash Transfer on Food Security and Nutrition: The Zambia Child Grant Programme. UK: Institute of Development Studies, 2014.

11. Davis B, Gaarderb M, Handac S, Yablonski J. Evaluating the impact of cash transfer programmes in sub-Saharan Africa: An introduction to the special issue. Journal of Development Effectiveness. 2012;4(1): 1-8.

12. Harvey C. Cash Transfers in Nairobi's slums: Improving food security and gender dynamics. Oxford, UK Oxfam GB, 2012.

13. MacAuslan I, Schofield L. Evaluation of Concern Kenya's Korogocho emergency and food security cash transfer initiative. Oxford Policy management, 2011.

14. Vincent K, Cull T. Impacts of social cash transfers: Case study evidence from across Southern Africa. Instituto de Estudos Sociais e Económicos, 2009.

15. Martins APB, Canella DS, Baraldi LG, Monteiro CA. Cash transfer in Brazil and nutritional outcomes: A systematic review. Rev Saúde Pública. 2013;47(6):115971.

16. Cotta RMM, Machado JC. The Bolsa Família cash transfer program and food and nutrition security in Brazil: A critical review of the literature. Rev Panam Salud Publica. 2013;33:154-60.

17. Adato M, Bassett L. What is the potential of cash tansfers to strengthen families affected by HIV and AIDS? A review of the evidence on impacts and key policy debatese. Washington DC: IFPRI, 2008.

18. Aguëro M, Carter MR, Woolard I. The impact of unconditional cash transfers on nutrition: The South African Child Support Grant. UNDP International Poverty Centre Working Paper 392007.

19. Maluccio J, Flores R. Impact evaluation of a conditional cash transfer program: The Nicaraguan Red de Protección Socia. Washington DC: International Food Policy Research Institute, 2004.

20. Mascie-Taylor C, Marks M, Goto R, Islam R. Impact of cash-for-work programme on food consumption and nutrition among women and children facing food insecurity in rural Bangladesh. Bull World Health Organ. 2010;88:854-60.

21. Yablonski J, O'Donnell M. Lasting benefits: The role of cash transfers in tackling child mortality. London: Save the Children Fund, 2009.

22. Slater R. Cash transfers: Graduation and growth, ODI Project Briefing 29. http://www.odi.org.uk/resources/download/3506.pdf, 2009.

23. Samson M, Williams M. The social and economic impact of cash transfers. Economic Policy Research Institute, Commissioned for DFID, 2007.

24. Kebede E. Moving from emergency food aidto predictable cash transfers: Recent experience in Ethiopia. Development Policy Review. 2006;24(5):579-99.

25. Hasani S. Ministry of Commerce and Targeting subsidies. Tehran: Ministry of Vommerce, 2010.

26. Tootoonchi-Maleki S. A brief study about basicexperimental studies in area of paydown subside in some countries Tehran: Economic Reseach Office, Islamic Parliament Research Center, 2008.

27. Vafaei-Yeganeh R, MousaviNik SH, Tabatabaei-Yazdi R. Assessment of the yearly Budjet Bill of Iran, 2012; Targeted subsidies. Tehran: Research Center of the Parliment, 2011.

28. Abdollahi M, Mohammadi F, Houshiar-Rad A, M MH, Esfarjani F. Shares of energy and nutrients intakes from subsidized food items in Iranian households in diffferent socio-economic status. Iranian Journal of Nutrition Sciences and Food Technology. 2011;6(1):43-56 (In Persian).

29. Pajouyan J. Comprehensive Study on Nutritional Practise and Food Security of Iranian Households. Tehran: Commercial Studies and Researches Foundation, 2005.

30. Mohammadi F, Omidvar N, Khoshfetrat AH-RM-R, Abdollahi M, Mehrabi4 Y. Validity of an adapted Household Food Insecurity Access Scale in urban households in Iran. Public Health Nutr. 2011;15(1):14957.

31. Mohammadi-Nasrabadi F. Evaluation of Subsidy Targeting Program through Cash Transfer on Food Security and Expenditure of Urban Population in Tehran: A Mixed Method. Tehran, IR Iran: Nationa Nutrition and Food Technology Research Institute, Academy of Medical Sciences, 2015.

32. Vedadhir A, Omidvar N, Mohammadi-Nasrabadi F, Khoshfetrat M, Zoghi T, Heidari H, et al. The Viewpoints and Satisfaction of Women with the Subsidy Targeting Program through Cash Transfer: A Qualitative Study in Tehran. Social Welfare Quarterly. 2016;In press.

33. Mahendra S. Poverty insights. Brighton: Institute of Development Studies, University of Sussex, 2009.

34. UNICEF. The livelihood empoverment against poverty (LEAP) programme: Reducing Poverty and Promoting Growth in Ghana. Ghana: Ministry of Gender, Children and Social Protection, 2013.

35. Dewbre J, Daidone S, Davis B, Miguelez B, Niang O, Pellerano L. Lesotho Child Grant Programme and Linking Food Security to Social Protection Programme. Rome: Food and Agriculture Organization of the United Nations, 2015. 
36. Baird S, McIntoshC, Özler B. Cash or Condition? Evidence from a Cash Transfer Experiment. The Quarterly Journal of Economics 2011;126(4):1709-53.

37. Román ER. Zimbabwe Emergency Cash Transfer (ZECT) Pilot Programme. UK Department for International Development (DFID), the Swiss Development Cooperation (SDC) and the European Commission Humanitarian Aid Office (ECHO), 2010.

38. Segall-Corrêa A, Marin-Leon L, Helito H, PérezEscamilla R, Santos L, Paes-Sousa R. Transferência de renda e segurança alimentar no Brasil: Análisedos dados nacionais. Rev Nutr. 2008;21(Supl):39s-51s.

39. Vianna R, Segall-Corrêa A. Insegurança alimentar das famílias residentes em municípios do interior do estado da Paraíba, Brasil. Rev Nutr. 2008;21(Supl):111s-22s.

40. Dias M, Machado H, Ferreira C ,Oliveira V, Gomes A, Cantaluppi E. Situação de insegurança alimentar de famílias beneficiárias de programas de transferência de renda na unidade de saúde da família comunidade São João Baptista, Petrópolis/ Rio de Janeiro. Rev APS. 2012;15(2):199-205 